\section{Vietnam extends scientific links}

IN March/April of this year, a fourman scientific delegation from the World Federation of Scientific Workers (WFSW) visited Vietnam. Professors E. H. S. Burhop (University College, London), J. M. Legay (SecretaryGeneral, WFSW, France), A. Matveef (Moscow University), and E. W. Pfeiffer (University of Montana) spent most of their ten-day stay visiting scientists in research institutes in both Hanoi and Ho Chi Minh City. A draft statement issued by the delegation reports that the Vietnamese scientists require as a matter of some urgency scientific literature; funds to purchase research equipment and supplies; and more contact with scientists abroad.

The delegation was impressed with the importance attached by the Vietnamese to science and technology. The object of the visit was to assess the scientific development of the country. But the group failed to elicit information on damage caused by the defoliation programme. Professor Pfeiffer, the US member of the delegation and a zoologist, is widely known for his campaign against the use of herbicides during the war in Vietnam. Pfeiffer was one of a handful of US scientists who campaigned relentlessly on this question and were instrumental in making it an issue of public debate. He told Nature that it was with some disappointment that he found the Vietnamese unwilling to take him to areas affected by herbicides; he points out their unwillingness to reveal information relating to the effectiveness of the spraying programme for fear that it could be used by the US in perfecting

\section{Bulgaria to shake up its scientific cooperation}

INTEGRATION and cooperation within Comecon-a basic aim of long-term Comecon planning -is undoubtedly a more tempting prospect to a lessdeveloped country such as Bulgaria than, say, Poland, where in 1976 the leading foreign affairs journal Sprawy Miedzynarodowe published some sharp criticism of this policy. But such cooperation holds a certain danger that the less-developed partner will become a mere passive recipent.

The Bulgarians, however, seem well aware of this hazard. Recently, reviewing joint Soviet-Bulgarian work in nuclear physics, Academician Kh.Y. Khristov, director of the Nuclear Research and Nuclear Power Institute of the Bulgarian Academy of Sciences observed "in the interests of truth" that "in fact, our participation, at least in the beginning, was not adequate. Usually the Soviet re- its chemical weapons.

As regards US scientists helping their Vietnamese colleagues, Pfeiffer feels that there is little that can be done by the individual "other than to work for the lifting of the embargo imposed by US Congress against trade with Vietnam and other essentially political activities". He mentions the delegation's visit to the IBM Computer Company in Ho Chi Minh City, where there are several million dollars worth of computers in operation at the moment. Spare parts and repairs will, however, be a problem in a year or so, and the Vietnamese are keen to establish relations with IBM. If this is not achieved, then Vietnam will have to turn elsewhere for assistance, probably to the socialist world. Pfeiffer therefore considers it to be most important that this fact be drawn to the attention of the politicians in Washington. He says that if the embargo continues for much

\section{Sorry, for copyright reasons some images on this page may not be available online}

US plane spraying defoliant, 1966

searchers were leading. They assigned the subjects or the methods (they often provided the devices themselves)." Gradually, said Khristov, the Bulgarian contribution has become greater.

Speaking at the National Conference of the Bulgarian Communist Party, Academician Angel Balevski, President of the Bulgarian Academy of Sciences recently observed that cooperation within Comecon, first and foremost with the Soviet Union, will continue to be the mainstay of Bulgarian science policy.

At present, he said, priority is being given to research aimed at mastering scientific and technical progress and its transfer to production-a trend reflected, incidentally, in Bulgaria's plan and budget for 1978 which allots 909 million leva to introducing scientific and technological developments into the economy, including 790 million leva for capital investments, and 450 million leva for the logistics of implementation. longer, the result would be that the Vietnamese would be forced into a political stance which America "spent billions [of dollars] for armaments to prevent".

India is one of the most recent countries to enter into a scientific aid agreement with Vietnam. The agreement, signed on 26 February this year during the visit to India of Pham Van Dong, prime minister of Vietnam, provides amongst other things for the exchange and training of scientists, the establishing of joint research programmes and the exchange of scientific and technical information. Some of the programmes will probably concern rice research, buffalo breeding and water resources management.

- Britain, too, appears to be improving its relations with Vietnam. On 2-15 May, Professor Ton That Tung, director of the Viet Duc Hospital in Hanoi, visited the UK as the guest of the Foreign and Commonwealth Office. Tung-one of Vietnam's leading medical practitioners, a surgeon researching into the treatment of liver carcinoma-met numerous scientists in the UK for discussions about his research interests. He told Nature that he hoped that his visit would lead to greater contact between scientists in Vietnam and the UK.

- The report of a five-man UN mission to Vietnam has been published. The team visited the country after the General Assembly's call for help in reconstruction. While providing facts and figures on the state of the country, the report offers little new information on damage to forests, and its section on the need for scientific and technological assistance is all too brief.

Alastair Hay

This trend, Balevski implied, will continue; as also will cooperation, since "a small country like Bulgaria cannot undertake the development of all scientific spheres."

He hinted however, that the development of research will in the future be more "selective"; while cooperation will be aimed at the "quality" rather than quantity of projects.

Academician Balevski did not specify what these projects will be. However, at the opening last week of an exhibition in Moscow commemorating the Bulgarian war of independence, $\mathbf{M r}$ Kosygin, former Soviet premier, stressed that existing plans call for close cooperation between the Soviet Union and Bulgaria in energy, ferrous metallurgy, machine-building, chemistry, electronics, agriculture, light industry and the food industry. Scienific cooperation, it may be assumed, will be closely linked to these broad economic aims. 